\title{
SELECTED ASPECTS OF TECHNOLOGICAL THOUGHT IN ECONOMICS ACCORDING TO THE CONDITIONS OF INDUSTRY 4.0
}

\author{
Tomas NĚMEC, Vaclav NÉTEK, Martin MYNÁŘ, Nikola NĚMCOVÁ, Iveta KUCHTIČKOVÁ \\ VSB - Technical University of Ostrava, Ostrava, Czech Republic, EU, tomas.nemec.st1@vsb.cz
}

https://doi.org/10.37904/metal.2020.3638

\begin{abstract}
The authors of the article generalize the results of research of a selected group of Czech industrial companies. These companies are founded on the experience of technological transformation in industry as a prerequisite for admission to technological chains which demonstrate high measurement accuracy and major changes in technological procedures.

The models of internal economic management are not sufficiently flexible to capture these changes as the investments in Industry 4.0 technologies are introduced. The results of investment research showed that the software used to manage the economics of the companies has lost its effectivity and needs replacement. One method of securing flexibility and continuity with Industry 4.0 dynamics is the application of economic thought in economics.
\end{abstract}

Keywords: Technological thought in economics, Industry 4.0, industrial and metallurgical companies

\section{INTRODUCTION}

Technological thinking is a fundamental method which transforms ideas into the material form of a specific product. We may distinguish between different ideas, such as business and the concept of usefulness and function of a product or the concept of an architect or builder. It therefore represents the manufacturability and feasibility of the design [1], [2]. We are familiar, as in the case of art, with the concept of a draft in industrial technology, i.e. a production drawing, where the size, final shape and a number of other aspects of the whole and individual parts are shown [4].

This idea is advanced into the technological stage, its result being not only manufacturability but also the order of operations required to implement the concept and time required to achieve the final result. This process is called the technological procedure and is the economic foundation for transforming engineering drawings into production drawing documentation.

The aim of the article is to draw attention to the findings of industry 4.0 and it's use to ensure flexibility and continuity in the application of economic thinking in the economy. The above-mentioned process is the basis for understanding the basic associations in business economics

The digitalization and automation of business and advanced manufacturing processes is becoming a requirement for successful organizations within different industries in order to remain competitive. Industry 4.0 represents the implementation and usage of technology that is alternating current traditional processes, aiming to enhance and improve them. Nowadays, many manufacturers and organizations are successfully transitioning to Industry 4.0 by realizing the advantages of digitized manufacturing and adapting highly datadriven and automated processes, which enable them to deliver improved services and products to customers [14]. Yet, the human factor seems not to be considered adequately in the Industry 4.0 processes, as most of the research efforts pursue enhanced performances through smarter technologies. Humans are usually only considered as consumers of the products and processes seem to work entirely without any human intervention. 
Various studies mention a lack of considering the human factor in the design-phase of the systems and highlight the need to consider it in the system design and to prepare the human operator with adequate skills in order to master and sustain the transformation towards Industry 4.0 [10-13]. Neglecting the humans in a complex system such as the Industry 4.0 will have impacts on the system performance and the system's ability to function safely and may lead to a complete breakdown of the concept [11]. Therefore, organizations that have adopted or are considering implementing the Industry 4.0 concept should consider all aspects, both technological and human, in their operations, as employees are the most important factor in these processes.

\subsection{Technological thinking}

Technological thinking is an integral part of business negotiations. The ability to understand and perceive price characteristics when calculating costs and real market prices is given by the ability to understand the technological process and its cost in the entire technological chain from the raw materials to final consumption. This is regardless whether cars, paper, or milk are produced. This also applies to the supply of so-called soft areas of the market, mainly services, if they penetrate technological or consumer chains. For the first time in 2011, Industry 4.0 was used. in Germany, and referred to the 4th goal. To connect the physical and virtual worlds in industrial production, which can be consolidated through new technologies. [5]. Figure 1 illustrates technological thinking $[3,9]$.

\section{Technological Thinking}

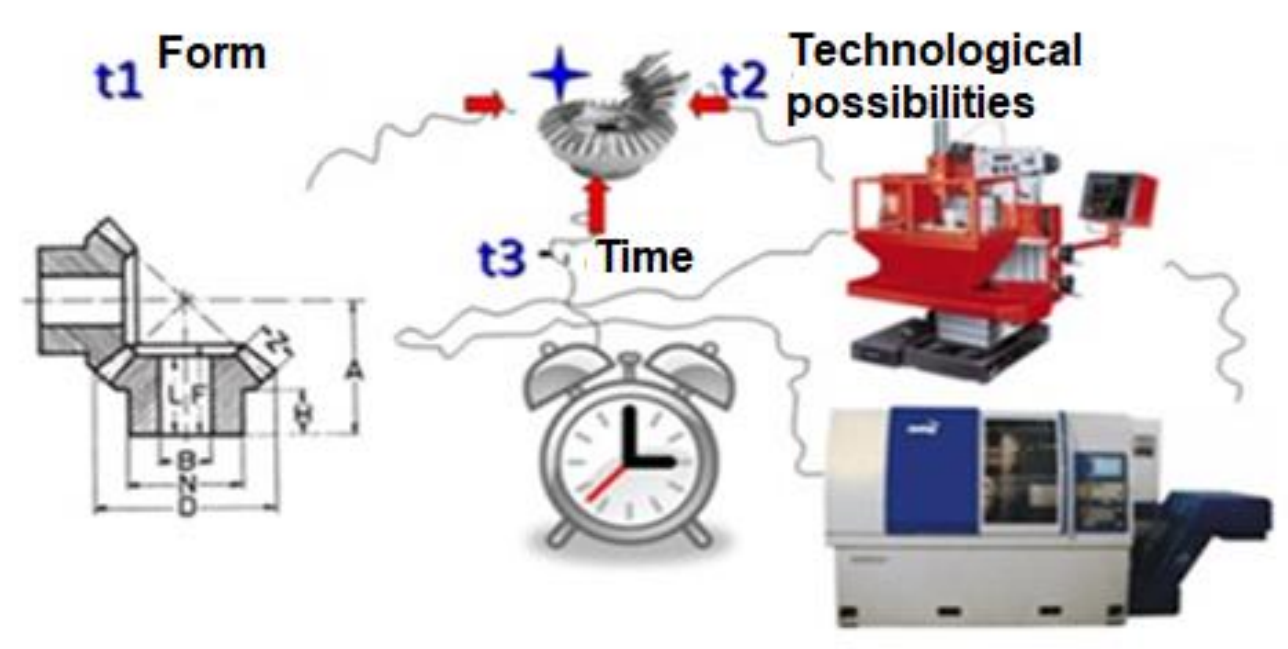

Figure 1 Technological thinking [4]

\subsection{Economic thinking}

Economic thinking is crucial in the transfer of time and performance characteristics into the final financial management process. Industry 4.0 formulates the basic principles of economic affairs of its administration contributing to the sustainable development of this industrial revolution and the digital world [7]. The fundamental pillar of economic thinking consists of systemic elements mainly involving tax accounting that illustrate the conditions and flow of the value processes indicated in balance sheets, profit and loss statements and cash flow. The result is a set of indicators which characterize the economic performance of the given business subject in relation to the rentability of the property and its liquidity as a tool for financial performance and the ability to pay its liabilities. Figure 2 illustrates economic thinking. 


\section{Economic thinking}

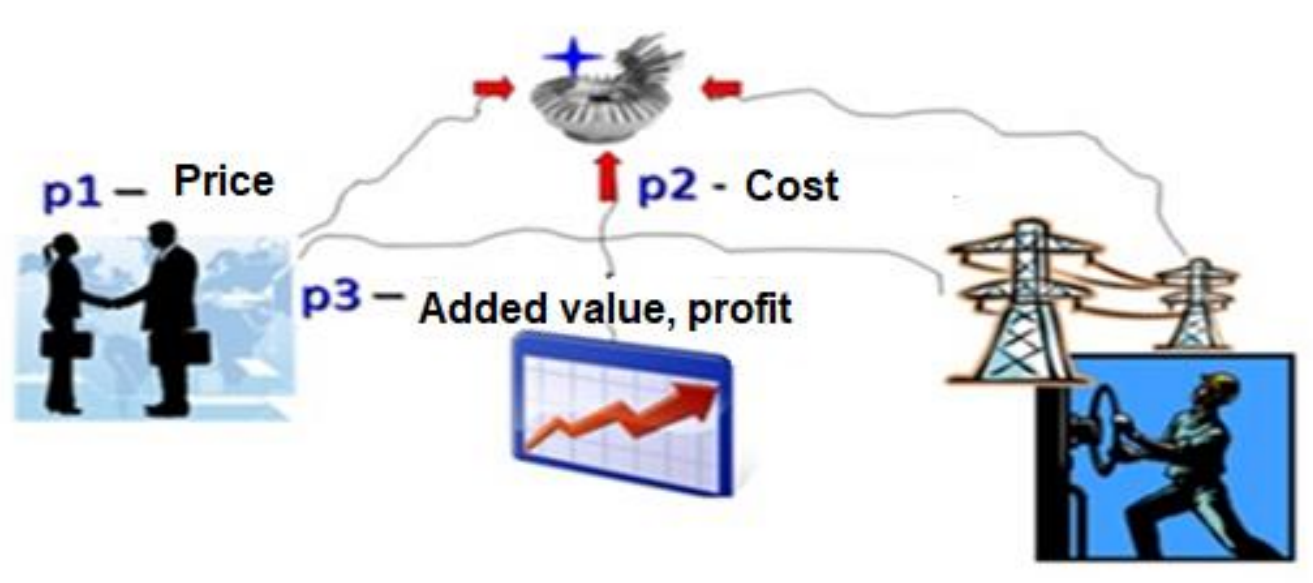

Figure 2 Economic thinking [4]

\section{RESEARCH RESULTS}

Czech industry consists of a very broad and extensive set of fields, given both by the historical factors in the development of Czechoslovakia and the result of a drastic transformation at the turn of the new millennium. The search for components which would form a continuous representation of available potential, which is located in the "Czech industrial basin", is a very complicated task. The aims of this monitoring study are as follows:

- $\quad$ Create a background map of the cooperative potential of Czech companies.

- Generalize the findings of research in potential behaviour and reactions in future cooperation with foreign investors.

- Generalize the findings of the attractivity of Czech engineering potential in terms of transferring the technological capacities of major world manufacturers.

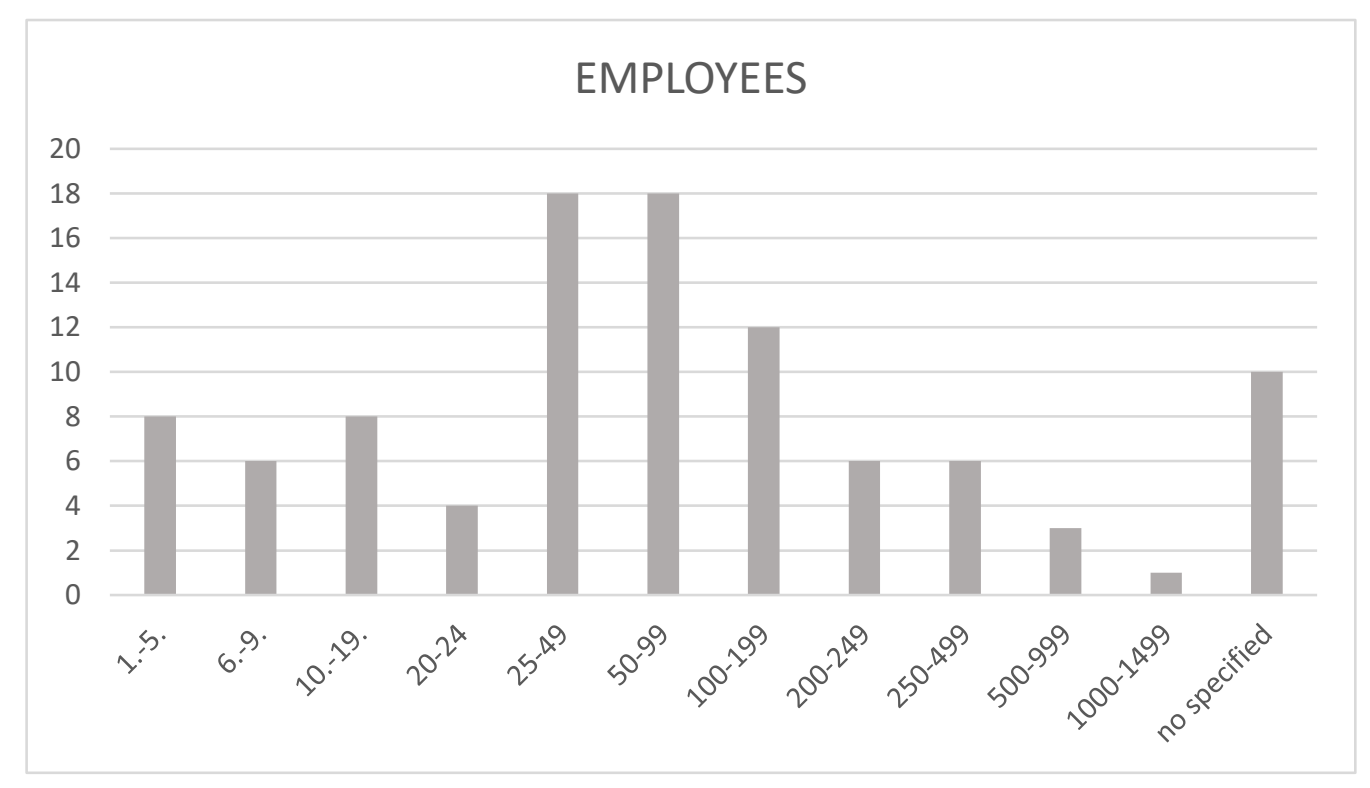

Figure 3 Chart of number of employees 
In terms of employee numbers, the largest group is represented by companies with 25-100 employees. Figure 3 shows a graph of the number of employees. The transition to industry 4.0 requires a great deal of effort to address the obstacles in the current environment of the organization, these obstacles are addressed at the same time for more sustainable resource management $[6,8]$.

In the next part of the monitoring research, it was necessary to create a methodological framework, whose purpose was mainly as follows:

- Obtain an overview of production and technological capacity.

- $\quad$ Create the possibility of comparing the concentration of individual technological groups.

- $\quad$ Create the possibility of displaying the interconnection of mutually different technological processes.

The findings of the research are given below:

\section{Finding 01}

The consequences of low ability of interbranch cooperation manifest mainly in export performance in terms of finalizing supplied products, technology and services. The ability to penetrate the market according to the degree of complexity of supplies is successfully employed by business and engineering organizations, mainly from sources located in the Czech Republic.

\section{Finding 02}

The automatization of large technological entities in the past 15 years with a high degree of specialization in technological devices/single-purpose devices has transformed traditional cooperative connections built on the sequence of operations which lead to finalizing a product.

To fill their capacity, new emerging individual business units which took over ownership of some technologies were forced to look for direct foreign sources/direct export without connections to the surrounding areas at the expense of work on several production operations or paid work.

\section{CONCLUSION}

The matter of the reciprocal relationship of technological and economic thinking becomes important with the ongoing application of Industry 4.0 technology. These technologies not only allow high productivity to be attained but also a high level of complexity and process integrity. This requires a change in how the economic performance of individual technological units in the technological chain is assessed. Systems of assessing performance economically according to economic centres and the processes for creating plans and directly calculating performance in relation to the costs of technological operations will undergo significant change in the management and decision-making process. The need for much greater synergy between technological and economic processes in real time is rising. The findings of the research presented in this article contribute to a deeper understanding of these processes.

\section{ACKNOWLEDGEMENT}

This work was developed under project SP 2020/61.

\section{REFERENCES}

[1] KOTLER, P., KELLER, K. L. Marketing management, 14th ed., New Jersey: PearsonEducation, Inc., 2011.

[2] KOTLER, P., KELLER, K. L. Marketing management, 14 ${ }^{\text {th }}$ ed., Praha: GradaPublishing, a.s., 2013.

[3] NÉTEK, V. Technologie průmyslového marketingu. Ostrava: VŠB - TU Ostrava, 2018, ISBN 978-80-248-4202-8.

[4] TONDL L. Technologické myšlení a usuzování. Filosofia, 1999, ISBN 978-80-7007-105-2. 
[5] BITTENCOURT, V.L., ALVES, A.C., LEÃO, C.P., Lean Thinking contributions for Industry 4.0: a Systematic Literature Review. IFAC-PapersOnLine. 2019, vol. 52, issue 13, pp. 904-909, ISSN 2405-8963, https://doi.org/10.1016/j.ifacol.2019.11.310.

[6] OZKAN-OZEN, Y.D, KAZANCOGLU, Y., MANGLA, S.K., Synchronized Barriers for Circular Supply Chains in Industry 3.5/Industry 4.0 Transition for Sustainable Resource Management. Resources, Conservation and Recycling. 2020, vol. 161, ISSN 0921-3449, https://doi.org/10.1016/j.resconrec.2020.104986.

[7] KOVACS, O. The dark corners of industry 4.0 - Grounding economic governance 2.0. Technology in Society. 2018, vol. 55, pp. 140-145, ISSN 0160-791X,2018, https://doi.org/10.1016/j.techsoc.2018.07.009.

[8] PEÑA, O.F.C, LLANOS, R. A., CORIA, M.D., PÉREZ-ACOSTA, A. M. Multidimensional Model of Assessment of Economic Thinking in College Students. Procedia - Social and Behavioral Sciences. 2015, vol. 191, pp. 16231628, ISSN 1877-0428, https://doi.org/10.1016/j.sbspro.2015.04.638.

[9] LEHTIMÄKI, T., SIMULA, H., SALO, J. Applying knowledge management to project marketing in a demanding technology transfer project: Convincing the industrial customer over the knowledge gap. Industrial Marketing Management, 2009, vol. 38, issue 2, pp. 228-236, ISSN 0019-8501, https://doi.org/10.1016/j.indmarman.2008.12.008.

[10] SAETREN GB, HOGENBOOM S, LAUMANN K. A study of a technological development process: Human factors-the forgotten factors? Cognition, Technology \& Work. 2016, vol. 18, issue 3, pp. 595-611, https://doi.org/10.1007/s10111-016-0379-x.

[11] KINZEL H. Industry 4.0-Where does this leave the Human Factor? Journal of Urban Culture Research. 2017 , vol. 15, pp. 70-83, ISSN: 2228-8279, https://doi.org/10.14456/jucr.2017.14.

[12] FANTINI P, PINZONE M, TAISCH M. Placing the operator at the centre of Industry 4.0 design: Modelling and assessing human activities within cyber-physical systems. Computers \& Industrial Engineering. 2020, vol 139, https://doi.org/10.1016/j.cie.2018.01.025.

[13] MIKULIC I., STEFANIC A. The Adoption of Modern Technology Specific to Industry 4.0 by Human Factor. In 29th DAAAM International Symposium on Intelligent Manufacturing and Automation. Vienna, Austria: DAAAM International, 2018, pp.0941-0946, ISBN 978-3-902734-20-4, ISSN 1726-9679, https://doi.org/10.2507/29th.daaam.proceedings.135.

[14] ANGELOPOULOU A., MYKONIATIS K., BOYAPATI R.N. Indrustry 4.0: The use of simulation for human reliability assessment. Procedia Manufacturing. 2020, vol. 42, pp 296-301, https://doi.org/10.1016/j.promfg.2020.02.094. 